\title{
Agricultural Ecological Compensation Policy Models in Developed Countries and China's Policy Development Process
}

\author{
Ying Zhou*1, Qingbo Zhou ${ }^{1}$, Shouwen Gan ${ }^{1}$ and Liying Wang ${ }^{2}$ \\ ${ }^{1}$ Institute of Agricultural Resources and Regional Planning, Chinese Academy of Agricultural Science, China \\ ${ }^{2}$ Institute of Agricultural Resources and Environment, Hebei Academy of Agricultural and Forestry Science, China
}

*Corresponding author: Ying Zhou, Institute of Agricultural Resources and Regional Planning, Chinese Academy of Agricultural

Science, China

\begin{tabular}{|c|c|}
\hline ARTICLE INFO & ABSTRACT \\
\hline Received: 豐 January 30, 2019 & Citation: Ying Zhou, Qingbo Zhou, Shouwen Gan, Liying Wang. Agricultural Ecologic \\
\hline Published: 幽 February 15, 2019 & $\begin{array}{l}\text { Compensation Policy Models in Developed Countries and China's Policy Development Pro- } \\
\text { cess. Biomed J Sci \& Tech Res 14(4)-2019. BJSTR. MS.ID.002589. }\end{array}$ \\
\hline
\end{tabular}

\section{Introduction}

Agricultural Ecological Compensation Policy Pattern in Developed Countries

Since the 1980s, developed countries have attached great importance to the formulation of incentive policies for farmers' environmental protection behaviors, implemented a series of compensation policy projects to promote environmental protection production, and formed a diversified agricultural ecological compensation models. The study summarizes the practice of foreign agro-ecological compensation policies and believes that developed countries usually adopt the following three typical compensation modes.

The US “Government-Led" Compensation Model: From the publication of the Agricultural Adjustment Act by the US government in 1933 to the revision and adjustment of the Agricultural Law in 2002, the us government invested a large amount of money every year to ensure the healthy and sustainable development of land through cost sharing, land renting, incentive subsidies, technical measures and other supporting policies [1,2]. For example, the US Green Agriculture Subsidy Program, and the agricultural environmental protection and support policy subsidies for land fallow, soil conservation, wetland reserves, environmental quality incentives, farm and pasture land protection, and grassland

reserves implemented, all in the form of cash assistance and technical assistance, which directly benefit farmers and internalize agricultural externalities [3,4].

EU's “Institutional Perfect" Compensation Model: The Common Agricultural Policy (CAP) of the European Union has shifted its focus to agro-ecological environmental protection and ecological restoration after many reforms, and has formed a sound agricultural ecological compensation operation system and an effective management mechanism [5,6]. Among them, the agricultural ecological compensation policy combines agricultural product price subsidies with environmental protection measures to guide farmers to adopt environmentally friendly production methods and reduce agricultural environmental pollution. A contract is established between the government and the farmers to evaluate the implementation effect of the project and the performance of the contract through a series of measures such as tracking monitoring and environmental assessment, which will serve as the basis for the government to reward and sanction the farmers in the future $[7,8]$.

Japan's “Environmental Protect" Compensation Model: In order to promote the development of environmentally-preserving agriculture, Japan has formulated and revised the "Agricultural 
Environment Three Laws" (referred to as "sustainable agricultural law", "livestock excretion law" and "fertilizer management law"). At the same time, it vigorously promotes the clean production technology of agriculture, and forms three agricultural models: "fertilizer and drug reduction, waste recycling and organic agriculture" $[9,10]$. In order to comprehensively promote the implementation of the environmental protection agricultural policy, the Japanese government has improved the policy mechanism of compensation for land, environment and regional resources preservation and adopted the practice of "high agricultural subsidies" to fully mobilize the enthusiasm of farmers in production [11].

\section{China's Agricultural Ecological Compensation Policy Course}

The agro-ecological compensation mechanism is a mechanism for formulating and implementing agricultural ecological compensation policies. Over the years, China has made certain progress in agro-ecological environmental protection. China has formulated and improved a number of laws and regulations on environmental and resource protection and introduced many compensation policies to promote the development of agricultural clean production [12]. However, under the influence of China's current agricultural subsidy policy and objective factors, the agricultural ecological compensation system is still not perfect and still lags behind the construction of ecological compensation system in forest, mining area, drainage area and ecological engineering [13]. During the period of reform and opening up (1978-2002), with the deepening of economic system reform, the agricultural subsidy policy also experienced a transition from vagueness to clarity, from indifference to strengthening, and gradually formed the agricultural subsidy policy system with price support and circulation link subsidies as the main part.

In the new era of reform and opening up (2003 now), as the country gradually enters the middle stage of industrialization, the implementation of industrial-backed agriculture and the overall urban and rural development has become the strategic focus of agriculture and rural areas. China has fully implemented its support and protection policies for agriculture, and has formed an agricultural subsidy policy system based on price support and directly subsidized. The system plays an important role in the development of agricultural modernization with Chinese characteristics [14]. Since 2004, the establishment and improvement of agricultural support and protection policies has become the focus of the first document of the Central Committee over the years. China's current agricultural subsidy policy system includes seven categories: first, agricultural support and protection subsidy policy based on "three subsidies"; Second, the local government financial award and subsidy policy, which is based on the reward of big counties producing grain (oil); The third is the production input and market regulation subsidy policy, which is mainly agricultural machinery purchase subsidy and circulation subsidy. Fourthly, it is a technical service subsidy policy based on agricultural production technology popularization. Fifth, it is the disaster loss type subsidy policy which mainly is the agricultural insurance subsidy; Sixth, agricultural ecological and environmental protection subsidy policy based on the protection of ecologically fragile areas; Seventh, farmers' living subsidy policy is mainly supported by the construction of rural public welfare undertakings [15]. China's current agricultural subsidy policy includes 17 aspects: food security, farmers' income, production tools, production materials, business entities, property rights system, organization, production technology, education and training, talent planning, ecological environment, natural disasters, agricultural insurance, engineering construction, public welfare undertakings, peasant life, financial investment.

\section{Acknowledgment}

This research was supported by "Fundamental Research Funds for Central Non-profit Scientific Institution (No.720-32)”. We would like to thank Professor Zhou Qingbo for his helpful comments and suggestions for revision. Furthermore, special thanks are owed to associate researcher Gan Shouwen and Dr. Wang Liying for participating in project investigation.

\section{References}

1. Sheingate AD (2000) Institutions and Interest Group Power: Agricultural Policy in the United States, France, and Japan. Studies in American Political Development 14 (2): 184-211.

2. David B, Richard NB (2004) Paper presented to International Agricultural Trade Research Consortium Adjusting to Domestic and International Agricultural Policy Reform in Industrial Countries [C]. Philadelphia p. 1-25.

3. Wallander S, Hand M (2011) Measuring the impact of the Environmental Quality Incentives Program (EQIP) on irrigation efficiency and water conservation. Agricultural and applied economics association. Agricultural and Applied Economics Association's 2011 AAEA \& NAREA Joint Annual Meeting[C] Pittsburgh: AAEA p. 1-4.

4. Wunder S, Engel S, Pagiola S (2008) Taking stock: A comparative analysis of payments for environmental services programs in developed and developing countries. Ecological Economics 65(4): 834-852.

5. Ulrich K, Malcolm DB (1990) The Common Agricultural Policy: A review of its operation and effects on developing countries. The World Bank Research Observer 5(1): 95-121.

6. L.XU (2008) EU Common Agricultural Policy development of and its reference. World Economic Situation (7): 14-20.

7. Koenig S, Simianer H (2006) Approaches to the management of inbreeding and relationship in the German Holstein dairy cattle population. Livestock Science 103(1): 40-53.

8. XP Yin, ZH Wang (2004) Cornerstone of European integration - EU Common Agricultural Policy. World Economic Research (7): 79-83.

9. Mulgan AG (2005) Where Tradition Meets Change: Japan's Agricultural Politics in Transition. The Journal of Japanese Studies 31(2): 261-298.

10. Zwart AC (1981) Japanese agricultural policy development: implications for New Zealand. Discussion Paper No.57 of Agricultural Economics Research Unit in Lincoln College. Canterbury New Zealand.

11. YC Li, M Weng (2006) Japan's Agricultural Policy Adjustment and Its Cause Analysis. Issues in Agricultural Economy (8): 72-75.

12. PX Li, W Sun (2010) Research on Regional Ecological Compensation 
Mechanism from the Perspective of Economic Geography. Ecology and Environmental Science 19(6): 1507-1512.

13. J Wan, HY Zhang, JN Wang, CZ Ge, ST Gao, et al. (2005) Policy evaluation and framework Discussion of ecological compensation in China Research of Environmental Sciences, 18(2): 1-8.

\section{ISSN: 2574-1241}

DOI: 10.26717.BJSTR.2019.14.002589

Ying Zhou. Biomed J Sci \& Tech Res

cC (i) This work is licensed under Creative Commons Attribution 4.0 License

Submission Link: https://biomedres.us/submit-manuscript.php
14. Nicholas R, CG Wang, LJ Qin (2015) Subsidy or market reform? Rethinking China's farm consolidation strategy. Food Policy 57: 93-103.

15. (2012) Ministry of Agriculture Press Office of China, China's agricultural subsidy policy has made a historic leap forward.

\begin{tabular}{ll} 
BIOMEDICAL & Assets of Publishing with us \\
RESEARCHES & - Global archiving of articles \\
\hline ISSN: $2574-1241$ & - Immediate, unrestricted online access \\
\hline
\end{tabular}

